\title{
MORAL PRINCIPLES TOWARDS A DEFINITION OF THE OBSCENE
}

\author{
Harold C. Gardiner, S.J.*
}

The problem proposed for discussion in this paper is, it seems to me-though I suppose I am egotistical to say it-the core problem of this symposium. It is all very well, of course, and most desirable that some agreement be reached as to what constitutes the obscene, and that a set of standards be evolved which will both safeguard the community and, at the same time, preserve individual freedom and the due process of the law, upon which, to a large measure, the protection of the civil society depends. But such safeguards and procedures will be but ephemeral things if they do not rest on some permanent basis of moral principle. So, too, must individual freedom, if it is not to be a thing protected today and endangered tomorrow, find its stability on the moral basis of the dignity of man.

Hence, in trying to formulate moral principles by which the obscene can be determined, we are at the nub of the whole matter. If, perhaps, I do not quite succeed in setting that nub forth in the clear light and with the persuasive force which it is capable of sustaining, let it be said at once that that is not because of the inexplicable density of the subject, but rather because of the fact that I am not a theologian in the sense of being engaged full-time in theological teaching or research, and second, because of the contributing factor that I shall, to some extent, be speaking a language that may be somewhat opaque to many readers. I shall try, however, to avoid, as far as I may, any "moralese"-the professional jargon of the textbooks-and to phrase my observations in the language of ordinary life.

That the editors of this symposium have been very much alive to the timeliness of the problem is perhaps demonstrated by the fact that last summer (June 28-30, 1954), the Catholic Theological Society of America, meeting in convention in Montreal, devoted one of its panel sessions to a discussion of this very topic, "Moral Principles for Discerning the Obscene." I was honored to be invited to read the paper and lead the ensuing discussion; and I should like to assure those readers who entertain the notion that Catholic theologians confine their discussions to fine-spun elucubrations concerning angels and needle-points that they would have been agreeably surprised at the practical nature of the two-hour question-and-answer period that followed the reading of the paper. The panel and its conclusions are reported in full in the proceedings of the Ninth Annual Convention; ${ }^{1}$ and some of this present paper will be in the nature of an expansion of what is contained in that report.

\footnotetext{
${ }^{2}$ Catholic Theological Society of America, Proceedings of the Nintth Annual Convrntion 127-39 (1954).

* S.T.L. 1935, Woodstock College (Md.); Ph.D. 194I, Cambridge University. Litcrary Editor, America, National Catholic weekly, since 1940. Author, Tenets for Readers and Reviewers (1942); Mysterifs' End (1945); Norms for the Novel (1953); Editor, The Great Books: A Chustian Appraisal (4 volumes, 1947-1952); Fifty Years of the Amierican Novel (1951).
} 
The first impression one gets, in considering what Catholic moral theology has to offer in the matter of defining the obscene, is that very little readily comes to hand. This may come as a surprise, especially to those who may have thought that the Catholic Church has succeeded in reducing life and thought to a precise set of neat axioms or has an exact formula to be applied in all contingencies.

It is quite true that Canon Law refers to obscenity with obvious severity. This occurs, of course, in the legislation of the Code of Canon Law that deals with the censorship of books (Canons 1385 -r 399 ). ${ }^{2}$ These passages do not lead us very far, however. We read in Canon I399, numbers eight and nine, for instance, as listed among general classes of literature that are forbidden to the reading of Catholics, books which "professedly (ex professo) discuss, describe or teach impure or obscene matters." But there is no definition, either here or in any other place in Canon Law, of what the obscene is. Legislation simply says that if a book is obscene, it is forbidden; it does not say what constitutes the obscenity. We shall soon see some samples of the interpretation of the legislation that have been offered.

This lack of precise definition in the Code may, as I have said, seem somewhat surprising, but perhaps it need not be so. When the codifiers produced the corpus of legislation now known as the Code, they were, as lawyers must be, at pains to clarify anything that seemed open to misunderstanding or obscurity, and their successors in the various Roman commissions are constantly receiving postulata (requests) from all parts of the world for clarification of such words and passages. We may presume, then, that since the word obscenum has rarely come up for any extended elucidation, it remains uncomplicated and clear in Catholic legal and moral thought; that it is, in fact, thought of as being rather self-evident.

This interpretation is strengthened when we examine the interpretations that actually have been given by canonists and moralists. These interpretations have been by no means exhaustive; they have generally been little more than somewhat sketchy paraphrases.

Before we turn to actual interpretations, let me preface with an aside. There is agreement among all that the word obscenum is to be interpreted, as far as possible, in a restricted sense (strictiori modo.) This is a corollary to the whole tenor of the interpretation of Canon Law, which declares that restrictive legislation (Canons that curtail freedom) is to be interpreted at its minimum extent; that is, human liberty is to be curtailed just as little as possible in the achievement of the ends of particular legislation.

Guided by this fundamental principle, canonists and moralists have been cautious not to widen the meaning of obscenum so as to include anything and everything that may be offensive to good taste or even to morals. So, for example, Noldin states: ${ }^{3}$

\footnotetext{
${ }^{2}$ Codex JURis Canonici 403 et seq. (I9x7). These canons and their interpretation can be most conveniently found in Redmond BURKe, What Is THE INDEX? (1952).

${ }^{3}$ H. Noldin, De Preceptis Dei et Ecclesiae 658 (r926).
} 
For a book to be prohibited [by reason of its obscenity], it is necessary that from its whole tenor the author's intention is evident of teaching the reader about sins of impurity and arousing him to libidinousness (ut prohibitus sit liber, requiritur ut ex tota ejus indole appareat scribentis intentionem lectorem de peccatis turpibus instruendi et ad libidinem excitandi).

Interpretations of this cautiously restricted nature have been re-echoed time and again by commentators on the Code. To quote but one recent commentary, Bouscaren-Ellis state that the ex professo phrase of the Code's prohibition "indicates the principal purpose of the author or the principal scope of the work"; moreover, in determining what that intention and scope are, Abbo-Hannan explain that "useful books imparting scientific information do not deal designedly with obscene matter as such and do not fall within this category" of obscene books. ${ }^{5}$

All this has not carried us very far along in our quest, but it may have sufficed to indicate that Canon Law and moral theologians, strict as they are in the matter of obscenity, especially in books, are not, may we say, "trigger-happy" to scatter shots against books that may, at first sight, seem to be obscene, but which more mature reflection will prove not to fall within the carefully restricted legislation.

But what is obscenity? The question remains.

The best lead to working out a satisfactory definition that has come to my attention is contained in a phrase-no more-that may elude the attention of the reader-whoruns of the famous Father Arthur Vermeersch, S.J., who wrote most extensively and lucidly on the matter of sex morality. Speaking of nudity in art, this wisely moderate moralist says: ${ }^{6}$

Not every nude can be called obscene; in common estimation an obscene nude is a nude that allures, and obscenity may be defined as 'a degrading manifestation or solicitation of the soul in the nudity.' (non omne nudum dici potest obscenum; sed vulgo dicitur obscenum nudum allectans et dici potest: turpis in nuditate manifestatio animi vel solicitatio.)

This suggestion seems to have been in the mind of the Rev. Gerald Kelly, S.J., when he wrote: ${ }^{7}$

The term obscenity is frequently used with a rather wide and vague meaning, but with the moral expert it is very technical. Let us illustrate from things to which the term is especially applicable, namely "obscene" literature and theatrical productions. For such things to be obscene, two elements are required: a) their theme, or content, is of an impure or sexually-exciting nature; and b) their manner of presentation is such as to throw an attractive emphasis on that impure or sexually-exciting element. For instance, adultery is a sin of impurity; so when a book or play not only centers about adultery, but portrays it in an attractive manner, such a book or play is obscene. Again, excessive nudity, and especially disrobing of a woman in the presence of a man, are commonly recognized as strongly stimulating to the sexual passions. Hence, when such things are alluringly emphasized and advertised ... they must be called obscene.

4T. Lincoln Bouscaren and Adam C. Ellis, Canon Law Digest 716 (1946).

${ }^{2} 2$ John A. Abbo and Jerome D. Hannan, The Sacred Canons 638 (1952) (italies supplied).

${ }^{\circ} 4$ Arthur Vermeersch, Theologiae Moralis 94 (1926).

${ }^{7}$ Gerald Kelly, Modern Youth and Chastity 73 (I94I). 
There may be a slight ambiguity to be cleared up here, especially in our efforts to determine what constitutes obscenity in literature. The "attractiveness" with which a theme, say of adultery, is treated may be taken in two senses. First, if the characters who commit adultery are to be portrayed convincingly, the adultery must be portrayed as attractive to them, else they would never have ventured on the downhill path. This follows from the general moral principle that no one ever sins save sub specie boni-he thinks and feels that he is getting some good. If I may quote myself: 8

But [sin] cannot be made so attractive that the reader, in his turn, is so swayed by the attractiveness as to have his judgment warped and his conduct misguided. Despite what will be said later [in the book] about the sympathy that good literature ought to foster between reader and character portrayed, the reader can never legitimately identify himself fully with the character. Those who think they are Napoleon are, after all, put away safely.

This is a psychological problem. . . A Authors have resorted to the phrase 'esthetic distance,' or 'psychical distance,' to describe the necessary detachment which enters into the contemplation of any artifact. If it is true that the viewer of a still-life, let us say, of a table spread with succulent viands should not experience the reaction of having his mouth water, it is equally true that one who reads of sin that proved fatally attractive to a character ought not feel himself drawn by the same attraction. But it is possible for a reader, too, to violate the 'esthetic distance' by unintelligent reading of a book that keeps the distance very well indeed.

Here we are approaching the heart of the matter. Before we plunge full in, allow me a slight digression which may have its interest especially to the legal approaches to the general subject which occupy other pages in this symposium. It is as follows.

The emphasis in Canon Law and in its continuing interpretation is always on the tendency of the book, of the work of art, to exude some sort of allure that panders to the passions of sex. This tendency is not to be judged by some sort of mystical reading of the mind of the producer. It is to be judged from objective elements in the thing produced; the author's "intentions" externalize themselves in his work. This is as much to say that the subjective element is a two-way street between the author and the reader or viewer. It is not to say that the judgment whether a certain artifact is actually obscene is a purely subjective decision. There are, moral teaching firmly declares, objective norms by which obscenity can be discovered. The main point of interest to the legal mind, however, is the remarkable similarity of advertence to the tendency of the work both in the discussions of the moralists and in legal decisions that were for a long time the basis for most of the legislation in both England and the United States.

I should be carrying coals to Newcastle if I were to expand on this point, so it may be sufficient merely to recall the famous (and recently rewritten) judgment handed

${ }^{8}$ Harold C. Gardiner, Norms for the Novel 53-54 (1953). 
down by England's Lord Chief Justice Cockburn in I868 which stated that the test of obscenity was ${ }^{\theta}$

... whether the tendency of the matter charged as obscene is to deprave and corrupt those whose minds are open to such immoral infuence, and into whose hands a publication of this sort may fall.

And, appositely echoing the views of the moralists that the whole tenor of the work must be taken into consideration (ex tota ejus indole), Judge Woolsey, in handing down the famous Ulysses decision in I933, stated: ${ }^{10}$

... the same immunity should apply to literature as to science, where the presentation, viewed objectively, is sincere, and the erotic matter is not introduced to promote lust and does not furnish the dominant note of the publication. The question in each case is whether the publication taken as a whole has a libidinous effect.

In order to determine the "libidinous effect," the alectatio underlined by Father Vermeersch, or the "attractive manner" emphasized by Father Kelly, it will be necessary to give a brief summary of moral teaching on the whole process of sex. That teaching holds, as a basic and cardinal fact, that complete sexual activity and pleasure is licit and moral only in a naturally completed act in valid marriage. All acts which, of their psychological and physical nature, are designed to be preparatory to the complete act, take their licitness and their morality from the complete act. If, therefore, they are entirely divorced from the complete act, they are distorted, warped, meaningless, and hence immoral. It follows, therefore, that any deliberate indulgence in thoughts, words, or acts which, of their intrinsic nature, are slanted toward, destined for, preparation for the complete act, and yet performed in circumstances in which the complete act is impossible, have ceased to be a means toward an end and have become ends in themselves. All sin, whether sexual or otherwise, always entails such a confusion, in one way or another, of means and ends.

There is a vast literature on this matter of the relation of means to ends, with special reference to the role of sex in life. One of the best popular expositions will be found in Christian Design for Sex, ${ }^{11}$ in which the author poses the very problem we are discussing. He asks "why may not man use sexual intercourse and seek the pleasure attached to it, contrary to its natural pattern?"12 $\mathrm{He}$ answers: "Because man is not the master of this function. Human life is God's domain . . . and

\footnotetext{
${ }^{\circ}$ Regina v. Hicklin, L.' R. 3 Q.B. 360 (1868). The recent case of Regina v. Martin Sccker and Warburg, Ld., [1954] $x$ Weekly L. R. II38, however, has been seen by many as resulting in a modification of the Hicklin rule. Mr. Justice Stable's summing up to the jury in this latter case can be found in the London Bookseller for July 17, 1954. The preceding and subsequent issucs of that trade magazine contain some very interesting comments on the whole matter of English concern for and treatment of obscenity in literature.

${ }^{10}$ United States v. One Book Called "Ulysses," 5 F. Supp. 182 (S.D.N.Y. 1933), aff'd, 72 F.2d 705 (2d Cir. 1934). The decision may be conveniently consulted in the Modern Library cdition of JAMIES JOYCE, UlysSES (1942), where it is printed in full with an introduction by Morris L. Ernst.

${ }^{12}$ Joseph Buckley, Christian Destgn for Sex (1952).

${ }^{12} \mathrm{Id}$. at 35 .
} 
so, likewise, is the process that leads to human life. A process belongs reductively to the same category as the object to which it leads." ${ }^{\text {13 }}$

It is for this reason that true sex morality has always held that any sins against purity are serious sins. Commenting, for example, on the statement of Father E. Mersch, S.J., that "the importance of the degree of the [sex] activity that has been aroused does not enter into the reckoning [of the gravity of the sin],"14 the translator of the book, one A.S., who also adds illustrative notes, goes on to say: $:^{15}$

Because, whether this voluntary activity of the sex instinct is more or less, the same essential consequences are involved, namely, the emotional consequences, which the author calls 'the psychological link' between the will and the bodily state, and the acceptance of this motion by the will, in virtue of its acceptance of the bodily sensation and activity which caused the emotion.

He then goes on to illustrate this idea, which would be accepted, I feel, by psychologists and even by the general public of this day when we hear so much of psychosomatic medicine: ${ }^{16}$

Thus, pressing the button of a small electric switch can start the most powerful machinery. The least voluntary degree of sex activity is like a switch which brings into action beyond our power of control "primordial forces that move in the depths of our nature." If it is always gravely sinful to bring these into action, except in conformity to moral law, it must be equally sinful to do what is to them the same as the pressing of the starting-switch is to all the machinery connected with it. It does not matter whether this activity be physical or mental ("bad thoughts"), for both kinds have the same effect on the deeper forces connected with them; that is, of course, provided they are voluntary.

The libidinous effect of the work, therefore-of which both the moralists and the law speak-can always be determined by an investigation of the tendency of the work to stimulate sexual passion. The reactions of the individuals may, of course, differ considerably-one may be more suggestible, the other more sluggish in his responses-but if the subject matter-the statute, the painting, the book-is such as, of its nature, to stimulate in the person of average sex instincts those preliminary commotions which are of their very nature preparatory for the complete sex act, then the subject matter has the character of stirring to libidinousness and is, consequently, obscene.

In order, however, to define this whole matter more closely, and to emphasize Father Kelly's important statement that, for the moralist, "obscenity" has a very precise meaning, it will be necessary to delimit what the moralists mean by "sexual passion." For sexual passion, pleasure that is called "venereal" is always concomitant. But there are three types of sense-pleasure that are not venereal. The following terminology may be a little technical, but I trust it will become clear as we explain.

The first non-venereal sense-pleasure has been named delectatio mere sensibilis:

${ }^{13}$ Id. at 37 .

14 E. Mersch, Love, Marriage, and Chasttty ig (i939).

${ }^{10}$ Ibid.

${ }^{10}$ Ibid. 
merely sensible pleasure. This has been described as "the pleasure proper to the harmonious functioning of the external senses."17 In other words, the senses-the taste, the smell, the sense of touch, and so on-reacting to a stimulation proper to themselves, experience a pleasure that perfects their operation; a pleasure that is not, per se, physically or psychologically geared to even a remote connection with the sexual act. So, a man feeling the delicate texture of a rose petal may indeed be sexually aroused, but, if he is, it is not something in the rose petal that had any connection with sexual activity. All the senses return a pleasure that is properly and uniquely theirs. If the pleasure fulfills the function of "perfecting operation," then the object which stimulates such pleasure cannot, of itself, be called an "obscene" object. A perverted person may misuse the object and read into it a lubricious character, but the object does not actually possess such a character.

The second non-venereal pleasure is called delectatio spiritualis-sensibilis: a psychosensible pleasure. This has been described as: ${ }^{18}$

... the satisfaction that a noble love takes in the external acts which are proper to the delectatio mere sensibilis [as outlined above]. It is essentially an act of the spiritual appetite which, nevertheless, has a redundance [an overflowing] on the sensitive appetite.

This "redundance" is often manifested physically in such ways as a rapid heartbeat, a mounting color and so on. Examples, such as the physical reactions of a mother greeting a long-unseen son, and so on, have been adduced to show this intimate connection between psychic and physical reactions. But, again, the point to be made is that there is no intrinsic connection between the pleasure experienced and the sex act.

Finally-and here we are on slightly more difficult ground-the third nonvenereal pleasure is delectatio carnalis-sensibilis: a pleasure carnally sensible. It is ${ }^{10}$

... the satisfaction taken in the same physical acts [as mentioned in the delectatio mere sensibilis] by a love which, though not strictly impure, is nevertheless carnal and strongly centered on physical characteristics.

Its psychic contours are quite different from the reactions mentioned in either of the two earlier non-venereal pleasures, and it is often the prelude to venereal pleasure. An example might be the physical pleasure experienced in the fondling of a child.

If this break-down by the moralists does not strike my readers as a little too fine-spun (I hope, rather, that it will strike them as a wonderful example of the care with which "obscenity" is not charged against every sensible human pleasure), it is perhaps clear that the peculiar characteristic by which these types of pleasure are distinct from venereal pleasure is that they have no intrinsic, no per se con-

\footnotetext{
${ }^{17}$ Gerald Kelly, The Theologian's Concept of Venereal Pleasure 270 et seq. (a doctoral dissertation presented in the Theological Faculty of Pontifical Gregorian University 1937).

${ }^{18}$ Ibid.

${ }^{20}$ Ibid. Father Kelly's treatise contains a full study of the approaches of earlier theologians to the matter.
} 
nection with genital commotion. It is this last element, the actual arousing of genital commotion, or the intrinsic tendency of an object so to arouse, which must be present if a book, a work of art, etc., can objectively be called obscene.

II

Such an approach to the question of defining obscenity, though it may strike one as being a mere process of rationalization, is actually an objective method. The distinction between venereal and non-venereal pleasure is one based on an objective study of how men actually do react, and it is a distinction that must be made if, as I mentioned above, the label of obscene is not to be slapped indiscriminately on works of art, on literary productions, which, of their nature, minister legitimately to a proper sense-pleasure.

This method of objective study, of determining moral norms from a consideration of men in action, is, of course, not of recent vintage, though the present-day emphasis on a sociological approach to morals often gives the impression that only nowadays are moralists concerned to sally forth from their ivory towers and consider man in his true human condition. Actually, however, the construction of moral science by the method of observation goes back to Aristotle. I would refer my reader here to the admirable The Confict between Exhics and Sociology, ${ }^{20}$ especially to chapter seven, "Toward the Solution," wherein the author expounds at length how St. Thomas Aquinas, following Aristotle, states, for example: ${ }^{21}$

In moral questions we must start with certain effects produced by human acts . . . because in moral questions the first principle is the existence of the moral act; and we attain knowledge of this existence by experience.

Again, St. Thomas states: ${ }^{22}$

It is necessary for anyone who wishes to be an apt student of moral science that he acquire practical experience in the customs of human life and in all ... civil matters, such as are laws and the precepts of political life.

If these principles by which we are attempting to define the obscene are based on the objective study of man in society, do they not, nevertheless, rest on a chimera? Do they not presuppose something that cannot be experimentally determined, name$\mathrm{ly}$, the existence of a uniform and normal human nature? It might seem that they do. The moralists quoted have referred constantly to those "of normal sex instincts," and a phrase they are fond of is homo quadratus, which we would translate, oddly enough, "the well-rounded man." And, speaking of such a man-if he existsFather Kelly says: ${ }^{23}$

There is one thing that must be presupposed in any man before venereal pleasure can be aroused, and that is . . . a disposition. Man must, in other words, have the appetite.

${ }^{20}$ Simon Deploige, The Conflict Between Ethics and Sociology (Chas. C. Miltner transl. 1938).

${ }^{21}$ Id. at 278 .

23 Id. at 274 n. 42.

${ }^{23} \mathrm{KeLLY}$, op. cit. supra note 13 , at 37-38. 
And this habitual disposition or latent appetite, should naturally pertain in some way to the parts that minister to the pleasure in question. Hence the natural constitution of man contributes the latent appetite, and the perception of the apt object is the stimulation that arouses the power from latency to activity. Thus ... man's perception of a venereally apt object by means of one of the external senses writes on his subjective apprehension: "Genital pleasure-something good for me, but absent": and nature's response is the actuation of the appetite in the form of venereal pleasure, an attempt to make the object present.

Does not such an approach presuppose that there is a uniformity of response to the appeal of the alluring object; a uniformity in human nature that is a figment of the moralists' imagination rather than a fact that can be experimentally shown? In other words, to reduce this general objection to the subject matter of this paper, does the nature of individual men so differ that it is impossible to set down some norms by which a certain thing can be called obscene? Is what is obscene for one capable of being not obscene for another?

As one might expect, St. Thomas has a great deal to say on this matter-not, it is true, with respect to obscenity, but in terms of the general problem of the immutability or variability of the moral law. Let it be said forthwith that St. Thomas, precisely because he worked from the data of experience, never affirmed that moral laws oblige "with the same force every reasonable free human being without distinction of time or place."24 Instead, as Deploige states: ${ }^{25}$

Anyone would have to be ill informed to believe that St. Thomas ignored the external world and was absorbed in drawing up a plan for the ideal state or a code of the perfect life, without any advertence to the possibility of the plan or the code being practicable. Before occupying himself with what ought to be, St. Thomas inquires into what is. And he observes precisely, as a fact of capital importance, the diversity of rules of conduct, of laws, and of institutions.

To give but a few instances of St. Thomas' grasp of reality in this matter:

Concerning virtuous works, men have no certain knowledge, but their judgments about them differ greatly. For there are works which are reputed just and upright by some, and, according to differences of time and place and persons, as unjust and dishonorable by others. Something is considered vicious at one time or place, which in another time or locality is not thought to be vicious. ${ }^{26}$

On account of the uncertainty of the human judgment, especially on contingent and particular matters, different people form different judgments on human acts; whence, also, different and contrary laws result. ${ }^{27}$

From this difference of opinion it happens that some believe that nothing is naturally just or honorable except by reason of positive laws. ${ }^{28}$

\footnotetext{
${ }^{24}$ This is the charge made by Levy-Bruhl in La Morale et la Science des Moesurs (1903), at 278. Deplotge, op. cit. supra note 20 , at 309 .

${ }^{25} I d$, at 3 ro.

${ }^{20}$ Id. at $3 \mathrm{II} \mathrm{n}$. I6r. The texts of St. Thomas to which this note and notes $27-35$ infra refer are quoted from the Burns and Oates edition, London.

${ }^{27}$ Ibid.

${ }^{28} I d$. at 3 II ก. 162.
} 
This "uncertainty of the human judgment" is caused by many things: by ignorance, by passion, and so on. Moreover, when, to return to our matter of the obscene, we are striving to lay down rules of conduct, it must be remembered that we are here in the realm of what St. Thomas calls the "practical reason," as distinguished from the "speculative," and $\mathrm{d}^{29}$

The practical reason is busied with contingent matters, about which human actions are concerned: and consequently, though there is necessity in the general principle, the more we descend into matters of detail, the more frequently we encounter defects.

This allowance for the variations in practise, however, does not mean that there is no immutability in principle, and it is the speculative reason that discovers the principles. St. Thomas will say, for example, over and over again:

There are certain actions naturally becoming to man, and in themselves right by nature, and not merely because they are prescribed by law..$^{30}$

Now the right ends of human life are fixed; wherefore there can be a natural inclination with respect to those ends. ${ }^{31}$

Here we pass, it seems to me, from the general principle which we have laid down from experimental data to the application of that principle to particular cases. We are, in other words, now dealing with the minor premise of a syllogism that runs:

Any object which per se tends to rouse the sexual passions is obscene.

But this particular object tends per se to rouse the sexual passions.

Therefore this particular object is obscene.

How may we take the step from theory to practise and determine that this particular object does have such a tendency? In the matter under discussion, the general principles which concern the ends of human life are the principles we have examined on the morality of venereal acts outside of marriage, even those preparatory acts whose whole bent is toward the complete act. On those principles, Catholic moralists are at one.

When we come to the use of the practical reason, however; when we come to the question "does this piece of literature, this work of art, actually rouse the average person to genital commotion, to sexual passion," there we are in the domain of probability, to some extent:

All discussions about things to be done must proceed on the ground of probability, not of certainty, for everything is contingent and variable in moral transactions. ${ }^{32}$

There is much uncertainty in things that have to be done; because actions are concerned with contingent singulars, which, by reason of their vicissitudes, are uncertain. ${ }^{33}$

These remarks of St. Thomas may perhaps be restated thus, with regard to our matter: It is certain that if this object rouses to genital commotion, it is obscene;
${ }^{20} \mathrm{Id}$. at 313 n. 170 .
${ }^{30} 1 d$. at 312 n. 165 .
${ }^{32} I d$. at 314 n. 170 .
${ }^{33}$ ld. at 313, n. 169 .
${ }^{31} I d$. at 316 n. I79. 
and it is obscene only if it so arouses; but it is not a matter of absolute certainty that this particular object will so arouse even the normal man. This, however, is not an impasse. Since, in these matters of the practical reason, what is looked for is action, we may lay down the further principle that, even if it is not certain that such and such an object will arouse to sexual passion, nevertheless, if the probability swings in that direction, then the object is, for practical purposes, obscene. Here are some of the observations of St. Thomas in this matter:

It is because the infinite numbers of singulars cannot be comprehended by the human reason, that our counsels are uncertain. Nevertheless, experience reduces the infinity of singulars to a certain finite number which occur as a general rule, and the knowledge of these suffices for human prudence. ${ }^{34}$

We must not seek the same degree of certainty in all things. Consequently, in contingent matters, such as natural and human things, it is enough for a thing to be certain, as being true in the greater number of instances, though at times and less frequently it fail. ${ }^{35}$

It would seem to follow, then, that though we cannot say with absolute certainty that such-and-such an object will infallibly rouse the viewer to sexual passions, yet if the object is of such a nature that it generally does so arouse, then for practical purposes we have a "law" for determining the obscene.

Here, by way of an aside, let me comment on St. Thomas' wise ideas-some expression of them, at any rate-on the matter of custom.

In all the discussions about defining the obscene-in the courts, by advisory counsel to publishers, and so on-perhaps not enough account is taken of what the ordinary man means and understands by obscenity. It is all very well to call upon "experts" to testify that such-and-such a work is not obscene, but in the effort to refine the definition to a razor-fine edge, perhaps the force of the common estimation is being watered down. Precision of definition is good, but not if it will blunt custom which knows pretty well what obscenity is. Here is one statement of St. Thomas' doctrine on law and custom: ${ }^{36}$

.. . change in human law is justified only to the extent that it benefits the general welfare. Now the very fact of change in the law is, in a certain sense, detrimental to the public welfare. This is because, in the observance of the law, custom is of great importance; so much so that any action which is opposed to general custom, even if itself of little importance, always seems more serious. ... Thus human law should never be changed unless the benefits which result to the public interest are such as to compensate for the harm done.

This brings the consideration of moral principles for determining the obscene to a close. There is little need to recapitulate, I feel. Perhaps two summary observations are in order.

First, as the discussion has brought out, moral theologians are not vague or too-far

${ }^{34}$ Id. at 276 n. 45 .

${ }^{35} \mathrm{Id}$. at $\mathrm{n} .46$.

${ }^{30} \mathrm{~J}$. V. Langmead Casserley, Morals and Man in the Social Sciences 57 (195x). 
ranging in their concept and statements of what constitutes obscenity or makes an object obscene. The word has a very precise meaning; it does not include such neighbors as "vulgar, distasteful, unpleasant, brutal," and so on. This, of course, is not to say that any moralist would therefore recommend for reading books that are "vulgar," and so on. But it does mean that obscene has a restricted meaning, which the whole tone and practise of moral theology and Canon Law refrains from extending to works, which, however much to be discouraged on other grounds, cannot be called objectively obscene.

Second, the determination whether this given work falls within that carefully staked-out definition is a matter of prudential judgment, in which there is no absolute certainty. In the dearth of such certainty, the probability that the work falls within the definition is enough to have the force of law.

In conclusion, let me say that, though I have not been able-nor, indeed, competent-to examine many of the legal decisions that have been handed down in this matter, I have been struck by the great amount of similarity existing between the approaches of the lawyers and the courts and the Catholic moralists in the matter of arriving at a workable definition. ${ }^{37}$ This is, surely, a fine thing and a good sign, for it shows that, though differences may and do exist, those interested in the civil and the moral law are linked in a common work of trying, in this difficult and delicate field, to work together for the common good.

${ }^{37}$ This similarity can be traced in the accounts carried, for example, in Thomas I. EMerson and David Haber, Political and Civil Rights in the United States 602-24 (1952), where, under "Freedom of Specch: Untruthful and Harmful Communication," section A is concerned with "Obscenity and Related Matters." 